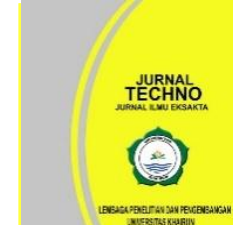

E-ISSN-2580-7129

Print- ISSN-1978-610X

JURNAL TECHNO (JURNAL ILMU EKSAKTA)

Jurnal homepage: http://ejournal.unkhair.ac.id/index.php/Techno

Volume 06 Nomor 02 Oktober 2017

\title{
Tinjauan Filogenetik Kupu-Kupu Ornithoptera spp. Berdasarkan Sekuen Mitokondria ND5 Gen
}

\author{
Abdu Masud $^{1 *}$ dan Abubakar Abdullah ${ }^{2}$ \\ 1,2Pendidikan Biologi, Universitas Khairun, Ternate \\ *Corresponding authors: e-mail: masudabdu.unk05@gmail.com \\ Manuscript received: 02-08-2017 Revision accepted: 28--09-2017
}

\begin{abstract}
Abstrak
Ornithoptera spp adalah salah satu kupu-kupu berukuran besar (makro lepidoptera) yang memiliki nilai estetika yang tinggi. Penyebaran kupu-kupu ini ditemukan di wilayah Maluku dan Papua. Salah satu aspek konservasi dari eksistensi kupu-kupu ini adalah database keanekaragaman dan kekerabatan. Oleh karena itu, tujuan dari studi kekerabatan Ornitoptera spp adalah untuk mengetahui hubungan kekerabatan Ornitoptera spp berdasarkan penanda molekuler gen ND5 pada mitokondria. Hubungan kekerabatan tersebut dapat dilihat dari pohon filogeni yang dikonstruksi berdasarkan sequence nukleotida pada gen ND5. Sequence gen ND5 diperoleh dari National Center for Biotechnology Information (NCBI) dan alignment sequence untuk konstruksi pohon filogenetik menggunakan program Clustal W yang diakses dari National Center for Biotechnology Information (NCBI) secara online. Pohon filogenetik menunjukkan bahwa Ornithoptera alexandea asal Papua New Guinea merupakan nenek moyang dari Ornithoptera spp. Onithoptera aesachus asal Pulau Obi dan Ornithoptera croesus asal pulau Bacan merupakan spesies Ornithoptera yang paling modern dan memiliki tingkat evolusioner termuda berdasarkan pohon filogenetik.
\end{abstract}

Kata kunci: Ornithoptera spp, filogenetik, ND5 gen.

\begin{abstract}
Ornithoptera spp is one of macrolepidoptera butterflies, its has hight aestehical value. The distribution of butterflies are found in Maluku and Papua region. One aspect as conservation of the exixtence butterflies is the database diversity and genetic relationship. The objectif of the research is to know genetic relationship of Ornithoptera spp based on moleculer marker of the ND5 gene mitokondrial. The genetic relationship can be knowed from the phylogenetic tree construction by sequence ND5 gene mitocondial. The Sequence ND5 gene is obstained from the National Center for Biotechnology Information (NCBI) and alignment sequence for the construction phylogenetic tree using Clustal W program acces from the National Center for Biotechnology Information (NCBI) online. The phylogenetic tree showed that Ornithoptera alexandea from Papua New Guinea is the ancestor for Ornithoptera spp. Onithoptera aesachus from Obi island dan Ornithoptera croesus from Bacan island is Ornithoptera's most modern spesies and has the youngest evolutionary level by phylogenetic tree.
\end{abstract}

Keywords: Ornithoptera spp, phylogenetic, ND5 genes. 


\section{PENDAHULUAN}

Salah satu anggota family Papilionidae adalah kupu Ornithoptera spp. Kupu ini merupakan salah satu jenis makrolepidotera yang memiliki nilai estetika yang tinggi (Mastrigt dan Rosariyanto 2005). Sebaran georafis kupu Ornithoptera spp antara lain di wilayah Maluku, Kepulauan Maluku Utara, papua Irian Jaya dan Papua new Guinea. Berdasarkan catatan Entomologis salah satu lokasi penyeberan kupu di wilayah Papua adalah Manokwari baik kawasan Arfak dan kawasan sekitarnya, termasuk wilayah Pantai Utara Manokwari (Hermawanto dkk,2015). Lebih lanjut dijelaskan lokasi penyebaran Ornithoptera di Maluku Utara adalah pulau Bacan, pulau Obi, pulau Halmaera dan Morotai ( Wallace, 1865; Mallet, 2004).

Beberapa spesies dari Ornithoptera spp merupakan kupu endemic dan dalam list status konservasi terancam punah (vulnerable). Jenis kupu-kupu yang endemik di Papua salah satunya adalah jenis Ornitoptera rothschildi, kupu endemic pulau Bacan adalah Ornithoptera croeseus, kedua kupu ini lebih dikenal dengan jenis kupu-kupu sayap burung. Kupu-kupu sayap burung (Ornitoptera priamus) ini bisa hidup di daerah pegunungan yang tingginya mencapai 0-2800 meter dari permukaan air laut. Di ketahui bahwa Cagar Alam Pegunungan Arfak merupakan salah satu wilayah utama distribusi species ini. Selanjutnya Cagar alam gunung Sibela pulau bacan merupakan wilayah utama distribusi Ornithoptera croesus.

Kupu-kupu merupakan bagian dari keanekaragaman hayati yang harus dijaga kelestariannya dari kepunahan maupun penurunan keanekaragaman jenisnya.Salah satu studi yang dapat dilakukan terhadap kupu endemic adalah dari bidang sistematika. Similaritas Ornitopthera sp dengan kupu lain dapat diketahui melalui studi taksonomi numerik dengan memanfaatkan data fenetik sebagai karakter. Sedangkan kekerabatannya dapat diketahui melalui konstruksi pohon filogenetik dengan memanfaatkan data molekuler.

Pada saat ini data molekuler organisme dari semua divisi yang berupa sequence DNA dapat diakses dengan relatif mudah dari bank data yang menyimpannya. Salah satu data molekuler yang dapat digunakan adalah sequence DNA untuk gen mitokondria ND5. Gen tersebut dapat dipergunakan sebagai penanda molekuler dalam penyusunan klasifikasi filogenetik karena gen tersebut terdapat pada mitokondria semua organisme termasuk kupu Ornithoptera spp. Ekspresi dari gen ND5 adalah protein fungsional NADH sub unit 5 yang berfungsi mengkatalisis respirasi sel secara aerob (Tabita et al., 2008). 
Masud dan Abdullah. Ornithoptera spp, FILOGENETIK, ND5 Gen.

Dalam klasifikasi filogenetik ini data sequence gen ND5 pada mitokondria kupu Ornithoptera spp yang disimpan di National Center for Biotechnology Information (NCBI) akan digunakan untuk mengkonstruksi pohon filogenetik yang menggambarkan kekerabatan evolusioner kupu Ornithoptera spp dari Maluku dan Papua. Pohon filogenetik adalah ilustrasi evolusi yang terjadi pada sekelompok organisme yang berasal dari nenek moyang yang sama, yang disusun berdasarkan kesamaan dalam beberapa hal, misalnya gen, protein dan organ (Ochieng et al., 2007).

\section{METODE}

Bahan: sekuens gen ND5 yang diunduh dari bank data internasional National Center for Biotechnology Information (NCBI).

Prosedur: Klasifikasi filogenetik kupu Ornithoptera spp ini dibuat dengan memanfaatkan data sequence DNA yang disimpan di bank data internasional NCBI dan program untuk konstruksi pohon filogenetik secara online yang disediakan oleh National Center for Biotechnology Information (NCBI). Identifikasi spesies secara online menggunakan data genbank pada NCBI (http://blast.ncbi.nlm.nih.gov/Blast.ncbi) dengan berbagai nomer akses dengan metode BLAST (Basic Local Alignment Search Tool) Selanjutnaya dilakukan alligment dengan menggunakan Clustal W vers. 1.4 (Thompson et al., 1994). Hasil alignment digunakan untuk mengkonstruksi pohon filogenetik yang visualisasinya dilakukan menggunakan program MEGA 6 (Tamura dkk. 2011). Jarak genetik dianalisis menggunakan metode Kimura parameter2 (Kimura, 1980) dan pohon filogenetik menggunakan metode Maximum Likelihood berdasarkan model Tamura-Nei (Tamura \& Nei 1993).

\section{HASIL DAN PEMBAHASAN}

Data karakter molekular yang diunduh dari NCBI adalah sequence gen ND5 mitokondria pada 12 spesies kupu Ornithoptera spp dengan berbagai kode akses seperti pada Tabel 1.

Tabel 1. Data Acession Number 12 spesies Ornithoptera spp.

\begin{tabular}{|c|c|c|}
\hline Nomor & Kode Accesion Number & Nama spesies \\
\hline 1 & AB 04055554 G.I 11990922 & O. croesus-Pulau Bacan \\
\hline 2 & AB 04055551 G.I 11990924 & O. aesacus-Pulau Obi \\
\hline 3 & AB $084436 \quad$ G.I 24450001 & O. chimaera-IrianJaya \\
\hline 4 & AB $084435 \quad$ G.I 24459999 & O. paradisea-Irian Jaya; Arfak \\
\hline 5 & AB 084433 G.I 24459930 & O. victoriae-Gela Papua New Guinea \\
\hline 6 & AB 04055556 G.I 11990926 & O. priamus-Timika Irian Jaya \\
\hline 7 & AB 04055553 G.I 11990920 & O. meridionalis-Timika Irian Jaya \\
\hline 8 & AB $084443 \quad$ G.I 24459915 & O. alexandrae-Papua New Guinea \\
\hline
\end{tabular}


TECHNO: Vol. 06 ( 02): 38-44, Oktober 2017

$\begin{array}{cccl}9 & \text { AB } 04055553 \text { G.I } 11990920 & \text { O. meridionalis-Irian Jaya } \\ 10 & \text { AB } 084434 & \text { G.I } 24450097 & \text { O. rothschildi-Irian Jaya } \\ 11 & \text { AB } 084433 & \text { G.I } 24450095 & \text { O. goliath-Irian Jaya } \\ 12 & \text { AB } 084432 & \text { G.I } 24450093 & \text { O. tithonus-Irian Jaya } \\ 13 & \text { LB } 242184 & \text { GI753050943 } & \text { P. ulysses morotaicus-Pulau Morotai } \\ 14 & \text { LB } 242183 & \text { GI753050942 } & \text { P. ulysses dohertius-Pulau Obi }\end{array}$

Pada data sequence gen ND5 yang tersimpan di NCBI memiliki panjang nukleotida kurang lebih 900bp. Jarak genetik dianalisis menggunakan metode Kimura parameter2 (Kimura, 1980) seperti pada table 2 berikut:

Tabel 2. Data Jarak Genetik Ornithoptera spp. Berdasarkan gen ND5 mitokondria dianalisis dengan metode Kimura 2 parameter .

\begin{tabular}{|c|c|c|c|c|c|c|c|c|c|c|c|c|c|}
\hline \multicolumn{14}{|l|}{ O. croesus-Pulau Bacan } \\
\hline O. aesacus-Pulau Obi & 0.037 & & & & & & & & & & & & \\
\hline $\begin{array}{l}\text { O. chimaera-IrianJaya } \\
\text { O. paradisea-Irian Jaya; }\end{array}$ & 0.062 & 0.082 & & & & & & & & & & & \\
\hline $\begin{array}{l}\text { Arfak } \\
\text {. }\end{array}$ & 0.062 & 0.085 & 0.065 & & & & & & & & & & \\
\hline $\begin{array}{l}\text { O. victoriae-Gela Papua } \\
\text { New Guinea } \\
\text {. }\end{array}$ & 0.074 & 0.074 & 0.074 & 0.086 & & & & & & & & & \\
\hline $\begin{array}{l}\text { O. priamus-Timika } \\
\text { Irian Jaya }\end{array}$ & 0.042 & 0.010 & 0.088 & 0.091 & 0.080 & & & & & & & & \\
\hline $\begin{array}{l}\text { O. meridionalis-Timika } \\
\text { Irian Jaya } \\
\text { O. alexandrae-Papua }\end{array}$ & 0.056 & 0.073 & 0.056 & 0.042 & 0.074 & 0.079 & & & & & & & \\
\hline $\begin{array}{l}\text { New Guinea } \\
\text { O. meridionalis-Irian }\end{array}$ & 0.076 & 0.074 & 0.083 & 0.080 & 0.105 & 0.077 & 0.057 & & & & & & \\
\hline Jaya & 0.056 & 0.073 & 0.056 & 0.042 & 0.074 & 0.079 & 0.000 & 0.057 & & & & & \\
\hline O. rothschildi-Irian Jaya & 0.064 & 0.070 & 0.051 & 0.088 & 0.085 & 0.065 & 0.070 & 0.074 & 0.070 & & & & \\
\hline O. goliath-Irian Jaya & 0.034 & 0.073 & 0.055 & 0.067 & 0.085 & 0.079 & 0.050 & 0.082 & 0.050 & 0.072 & & & \\
\hline $\begin{array}{l}\text { O. tithonus-Irian Jaya } \\
P . \text { ulysses morotaicus- }\end{array}$ & 0.074 & 0.097 & 0.085 & 0.087 & 0.104 & 0.098 & 0.081 & 0.089 & 0.081 & 0.079 & 0.073 & & \\
\hline $\begin{array}{l}\text { Pulau Morotai } \\
P . \quad \text { ulysses dohertius- }\end{array}$ & 0.149 & 0.168 & 0.159 & 0.160 & 0.182 & 0.176 & 0.162 & 0.150 & 0.162 & 0.168 & 0.147 & 0.170 & \\
\hline Pulau Obi & 0.156 & 0.169 & 0.163 & 0.164 & 0.179 & 0.176 & 0.162 & 0.151 & 0.162 & 0.168 & 0.155 & 0.171 & 0.005 \\
\hline
\end{tabular}

Nilai jarak genetic pada kupu Ornithoptera spp diketahui bahwa Ornithoptera priamus memiliki nilai jarak genetic terkecil, selanjutnya Ornithoptera . aesachus Obi dan Ornithoptera goliath sedangkan $O$. thitonius memiliki nilai jarak genetic terbesar. Selanjutnya data hasil alignment menggunakan program Clustal W ver 1.43 yang dilakukan pada sequence ND5 Ornithoptera spp dapat digunakan untuk mengkonstruksi pohon filogenetik yang menggambarkan hubungan evolusioner, Pohon filogenetik yang dikonstruksi berdasarkan gen mitokondria ND5 Ornithoptera spp seperti Gambar 1. 


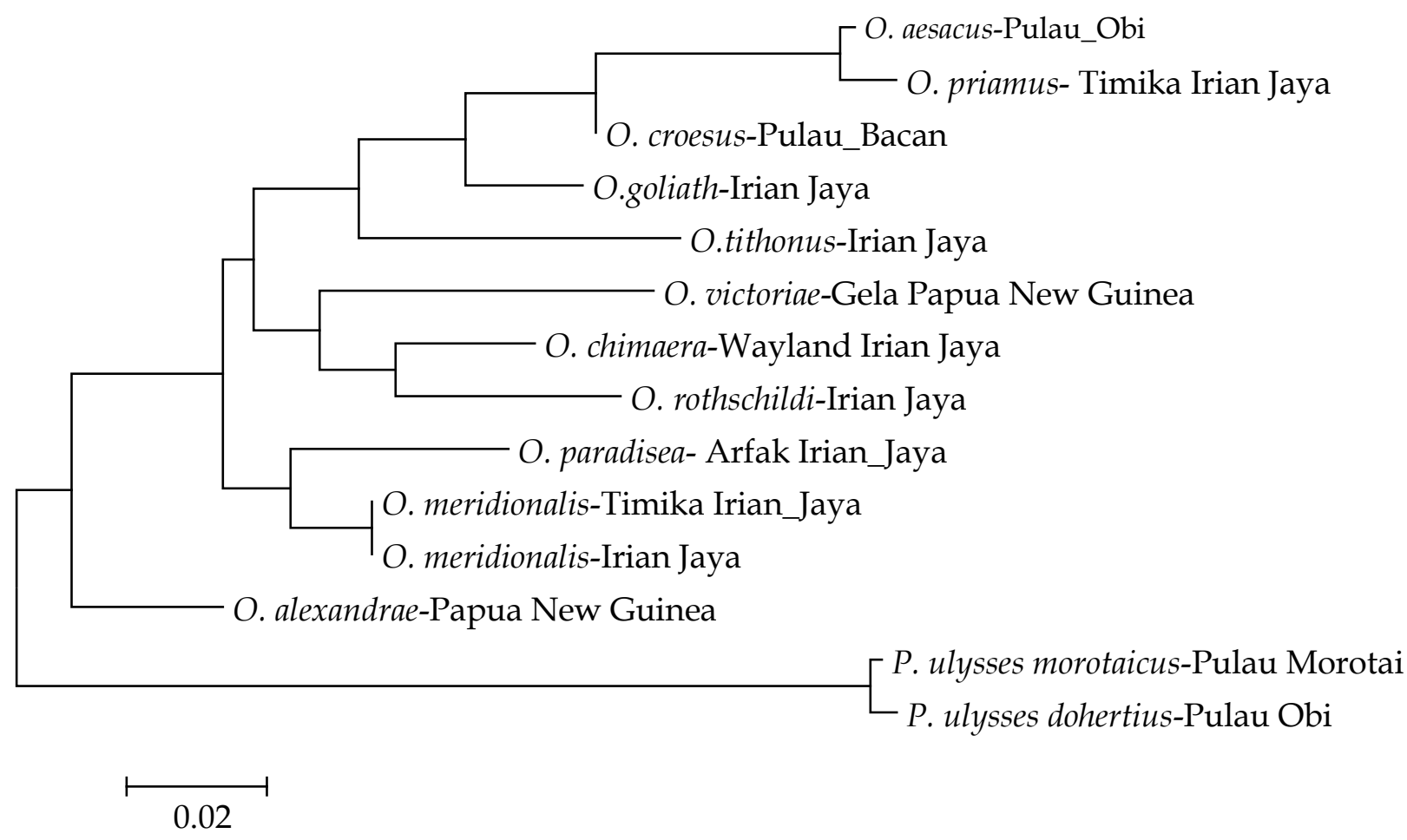

Gambar 1. Pohon Filogenetik Ornithoptera spp. Berdasarkan gen Nd5 Mitokondria

Pada pohon filogenetik tersebut diketahui bahwa terbentuk dari 4 klaster utama dengan outgroup Papilio Ulyses spp. Pohon filogenetik selain menunjukkan kekerabatan antar spesies yang diperbandingkan, juga menggambarkan perubahan yang terjadi pada gen penanda untuk masingmasing spesies. Semakin panjang suatu cabang artinya semakin banyak perubahan yang terjadi pada gen penanda selama proses evolusi, akibatnya spesies yang berada pada cabang tersebut dapat dikatakan lebih maju.

Berdasarkan hasil analisis menggunakan pohon filogenetik di atas diketahui bahwa Ornithoptera alexandrea Papua New Guinea merupakan ancestor dari Ornitoptera spp. Selanjutnya Ornithoptera paradise Papua dan O. meridionalis Papua merupakan kerabat dekat dalam satu kluster. Kupu O. victoria Papua, O chimera Papua dan O. rotschidii Papua merupakan kerabat dekat dalam satu kluster. Untuk O. thitonius, O goliath, O. Croesus, O priamus dan O aesacus merupakan kupu Ornithoptera spp. kluster termuda dan paling modern. Menurut Ochieng et al. (2007) pohon filogenetik tersusun atas 
nodus-nodus dan percabangan. Masing-masing nodus menggambarkan proses spesiasi selama terjadinya evolusi. Nodus-nodus ujung mewakili data yang dibandingkan (operational taxonomic units), sedangkan nodus internal melambangkan unit nenek moyang (hypothetical taxonomic unit). Panjang masing-masing cabang mewakili jumlah perubahan yang terjadi pada karakter yang digunakan sebelum terjadinya separasi berikutnya. Oleh karenanya, karakter yang sangat mirip akan berdekatan di dalam percabangan. Salah satu tahap penting dalam mengkonstruksi pohon filogenetik adalah alignment, yaitu membandingkan sisi yang homolog-homolog dan variablevariabel antar sequence sehingga diperoleh nilai similaritas.

Hasil analisis filogenetik dalam tulisan ini dapat digunakan sebagai informasi awal dalam kajian biosistematika dan taksonomi kupu kupu di Maluku Utara. Data dalam tulisan ini merupakan analisis awal dalam riset kajian diversitas intraspesies kupu Ornithoptera Croesus endemic pulau Bacan berdasarkan karakter morfologi dan Molekuler. Selanjutnya hasil hasil penelitian berikutnya merupakan databse yang dapat digunakan untuk menentukan strategi konservasi satwa endemic khususnya kupu kupu di Maluku Utara.

\section{KESIMPULAN}

Kajian kekerabatan pada kupu Ornithoptera spp menggunakan data molekuler sekuen dari gen ND5 mitokondria pada genbank NCBI diperoleh informasi bahwa terdapat hubungan kekerabatan antara kupu Ornithoptera spp asal Papua, dan Maluku Utara. Kupu Ornithoptera alexanrea asal Papua New Guinea merupakan nenek moyang dari kupu Ornithoptera spp. Kupu Ornithoptera aesachus asal Obi dan Ornithoptera Croesus asal Bacan merupakan kelompok kupu Ornithoptera yang paling modern dengan tingkat evolusi termuda berdasarkan analisis pohon filogenetik.

\section{UCAPAN TERIMAKASIH}

Penulis mengucapkan terimaksih tak terhingga kepada Dr Abdul Hamid A Toha, M.Si dan Dr Sundari M.Pd serta Didik Wahyudi M.Si atas tutorial dan asistensinya dalam Bioinformatika dan analisis data molekuler sehingga penulisan artikel ini bisa terlaksana. 


\section{DAFTAR PUSTAKA}

Hermawanto Rudi, Rawati Panjaitan, Sepus Fatem. 2015 Kupu-Kupu (Papilionoidea) Di Pantai Utara Manokwari, Papua Barat: Jenis, Keanekaragaman Dan pola distribusi Prosiding Seminar Naional s Masyarakat Biodiversitas Indonesia. Volume 1, Nomor 6, September 2015 ISSN: 2407-8050 Halaman: 1341-1347

Mastrigt H van, Rosariyanto E. 2005. Buku Panduan Lapangan Kupu-kupu Untuk Wilayah Mamberamo Sampai Pegunungan Cyclops. Conservation Internasianal. Jakarta.

Mallet, J. 2004. Poulton, Wallace and Jordan: how discoveries in Papilio butterflies initiated a new species concept 100 years ago. Systematics and Biodiversity 1(4):441-452.

Ochieng, J. W. , Muigai, A.W.T., and Ude, G.N. 2007. Review: Phylogenetics in plant biotechnology: principles, obstacles and opportunities for resource poor. African Journal of Biotechnology Vol. 6 (6): 639-649.

Tabita, F.R., Hanson, T.E., Satagopan, S., Witte, B.H., and Kreel, N.E. 2008. Review: Phylogenetic and evolutionary relationships of RubisCO and the RubisCO-like proteins and the functional lessons provided by diverse molecular forms. Phil. Trans. R. Soc. B. 363: 2629-2640.

Tamura K., Nei M., and Kumar S. (2004). Prospects for inferring very large phylogenies by using the neighbor-joining method. Proceedings of the National Academy of Sciences (USA) 101:11030-11035

Tamura K., Stecher G., Peterson D., Filipski A., and Kumar S. (2013). MEGA6: Molecular Evolutionary Genetics Analysis version 6.0. Molecular Biology and Evolution30: 2725-2729.

Wallace, A. R. 1865. On the phenomena of variation and geographical distribution as illustrated by the Papilionidae of the Malayan region. Transactions of the Linnean Society of London 25:1-71. 